\title{
Metalloid mobility of aged landfill - the negative impact of the forgotten
}

\author{
MARIJA PETROVIĆ ${ }^{1}$, ŽELJKA FIKET $^{1}$, MATEJ \\ DOLENEC $^{2}$, BRANKO ČERMEL $J^{3}$, GORDANA MEDUNIĆ ${ }^{4}$ \\ AND MAJA IVANIĆ ${ }^{1}$ \\ ${ }^{1}$ Ruđer Bošković Institute \\ ${ }^{2}$ Faculty of Natural Sciences and Engineering, University of \\ Ljubljana \\ ${ }^{3}$ National Institute of Biology \\ ${ }^{4}$ Faculty of Science, University of Zagreb \\ Presenting Author: petrovic@irb.hr
}

Due to exposure to various external factors, aged industrial waste has different physiochemical properties than waste originally disposed of. One of such aged landfills is found in Croatia, where a long history of coal combustion [1,2] left behind alkaline ash and slag waste. The waste was exposed to external conditions for more than 20 years, which resulted in the leaching of elements and pollution of the local area [3].

Currently, the landfill is characterized by a slope that is mostly bare. Due to partly revegetation of landfill, it is assumed that landfill has undergone intrinsic changes such as the addition of organic matter.

To assess the undergone changes, the total content of macronutrients $(\mathrm{N}, \mathrm{P}, \mathrm{K}, \mathrm{Ca}, \mathrm{Mg}, \mathrm{S}$ ) and organic content was determined in landfill samples. The Leachability of oxyanions (V, Se, Mo) was assessed to determine the limiting factor for further succession.

The content of both $\mathrm{C}$ and $\mathrm{N}$ was higher in aged waste samples compared to the 'fresh' ashes values previously reported [4]. However, the ratio of $\mathrm{C}: \mathrm{N}$ was lower in aged waste than fresh samples, indicating the addition of organic matter. The organic content was found lower than in reported 'fresh' ashes, indicating the transformation of the waste.

All samples showed an increase in nutrient content compared to reported values in 'fresh' ashes [4]. However, nutrient concentrations vary across the landfill, reflecting the partial vegetation of the site. From measured oxyanions, Mo seems to be the limiting factor in a further succession of the landfill. Considering that Mo extract concentrations are above the regulatory value, the aged waste still poses a threat to the environment, even decades after its disposal.

\section{References}

[1] Medunić, Ahel, Božičević Mihalić, et al. (2016), Science of the Total Environment 566-567, 306-319.

[2] Medunić, Kuharić, Krivohlavek, et al. (2017), International Journal of Oil, Gas and Coal Technology 18(1/2), 3-24.

[3] Fiket, Medunić, Vidaković-Cifrek, et al. (2020), Environmental Science and Pollution Research 27, 6613-6627.

[4] Lieberman, Izquierdo, Muñoz-Quirós, et al. (2020), Applied Geochemistry 114, 104472.

\section{Acknowledgement:}

This work has been supported by Croatian Science Foundation under the project IP-2019-04-9354 (FORtIS). 